\title{
Obesity, Type 2 Diabetes and Beta Cell Failure: An Asian Perspective
} Yoshifumi Saisho*

Department of Internal Medicine, Keio University School of Medicine, Japan

\begin{abstract}
Type 2 diabetes (T2DM) is characterized by insulin resistance and beta cell dysfunction. Although both factors are hallmarks of T2DM, evidence from recent studies has emerged showing that impaired beta cell function is always present in humans with T2DM, suggesting that beta cell dysfunction is a core factor in the pathogenesis of T2DM. Deficit of beta cell mass in humans with T2DM has also been reported, probably through an increase in beta cell apoptosis. Whether deficit of function or mass of beta cells is more important in beta cell dysfunction in T2DM remains unclear; however, collectively, functional beta cell mass is decreased in humans with T2DM. Beta cell dysfunction is not only present in T2DM but also progressively worsens with duration of the disease. Recent studies have also revealed that the functional beta cell mass is already impaired before the onset of T2DM, implying that beta cell dysfunction is essential in the development of T2DM. Finally, ethnic difference in beta cell function has also been proposed. Recent studies suggest that Asians have less beta cell functional capacity compared with Caucasians. Therefore, preservation or recovery of functional beta cell mass is an important therapeutic strategy to prevent, treat and even cure T2DM, and this seems to be further emphasized for Asians.
\end{abstract}

Keywords: Beta cell function; Beta cell mass; Type 2 diabetes; Ethnic difference

Abbreviations: T2DM: Type 2 Diabetes; IDF: International Diabetes Federation; IGT: Impaired Glucose Tolerance; IFG: Impaired Fasting Glycemia; NGT: Normal Glucose Tolerance; BMI: Body Mass Index; OGTT: 75g-Oral Glucose Tolerance test; HOMA-IR: Homeostasis Model Assessment of Insulin Resistance

\section{Introduction}

The number of patients with type 2 diabetes (T2DM) is continuously increasing throughout the world. According to the International Diabetes Federation (IDF), approximately 382 million people worldwide, or $8.3 \%$ of adults, were estimated to have diabetes in 2013, and approximately 592 million people, or $10 \%$ of adults, will have diabetes in 2035 [1]. Nonetheless, there is still no effective strategy to reduce this burden.

T2DM is characterized by insulin resistance and beta cell dysfunction. Since a rather higher plasma insulin level was found in patients with T2DM following the development of a radioimmunoassay for insulin, insulin resistance has been emphasized as a cause of T2DM in contrast to type 1 diabetes, and it has been often assumed that T2DM is a disease of "insulin resistance" over the last several decades.

However, recent studies have consistently shown that people with T2DM have reduced beta cell function and even beta cell mass, indicating that beta cell failure is central in the pathogenesis of T2DM [2-4]. Furthermore, recent studies have suggested that beta cell failure in T2DM is more apparent in Asians than in Caucasians $[5,6]$. This review summarizes the current understanding of beta cell failure in T2DM and discusses its clinical implications.

\section{Insulin Secretion-Sensitivity Relationship}

In a physiological condition, insulin secretion and insulin sensitivity are balanced. If insulin sensitivity is decreased, insulin secretion increases to maintain normoglycemia. Therefore, this relationship between insulin secretion and insulin sensitivity is expressed as a hyperbola (Figure 1). In patients with T2DM, a higher plasma insulin concentration is often found. However, based on this relationship, higher plasma insulin simply reflects greater insulin demand due to decreased insulin sensitivity. Thus, true beta cell function needs to be assessed with adjustment for concomitant insulin sensitivity, the socalled disposition index developed by Bergman et al. $[7,8]$.

Since the insulin secretion-insulin sensitivity relationship is hyperbolic, the disposition index, i.e., the product of insulin secretion and insulin sensitivity, is constant as long as normoglycemia is maintained. However, once the increase in insulin secretion fails to compensate the decrease in insulin sensitivity, the hyperbolic curve shifts to the left and glucose intolerance develops. As a result, the disposition index decreases (Figure 1) $[9,10]$.

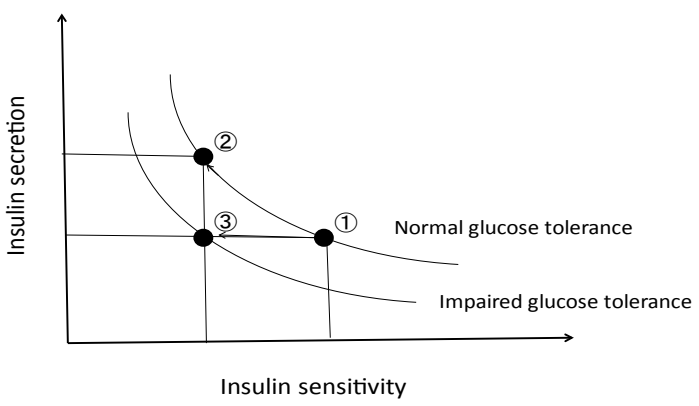

Figure 1: Insulin secretion-insulin sensitivity relationship. In a physiological condition, when insulin sensitivity decreases, insulin secretion increases to maintain normoglycemia $(1 \rightarrow 2)$, showing a hyperbolic curve. When insulin secretion fails to compensate, the hyperbolic curve shifts to the left and abnormal glucose tolerance develops $(1 \rightarrow 3)$.

${ }^{*}$ Corresponding author: Yoshifumi Saisho, MD, PhD, Department of Interna Medicine, Keio University School of Medicine, 35 Shinanomachi, Shinjuku-ku, Tokyo 160-8582, Japan, Tel: +81-3-3353-1211 (x62383); Fax: +81-3-3359-2745; E-mail: ysaisho@z5.keio.jp

Received November 30, 2013; Accepted December 26, 2013; Published January 02, 2014

Citation: Saisho Y (2014) Obesity, Type 2 Diabetes and Beta Cell Failure: An Asian Perspective. J Mol Genet Med S1: 008. doi: 10.4172/1747-0862.S1-008

Copyright: (c) 2014 Saisho Y. This is an open-access article distributed under the terms of the Creative Commons Attribution License, which permits unrestricted use, distribution, and reproduction in any medium, provided the original author and source are credited 


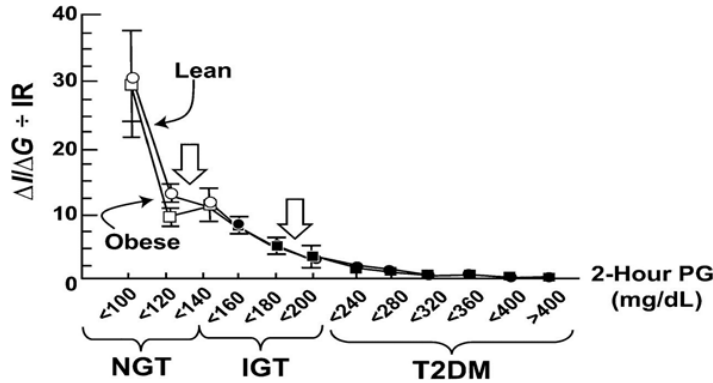

Figure 2: Insulin secretion/insulin resistance (disposition) index $(\Delta \mathrm{l} / \Delta \mathrm{G}$ $\div \mathrm{IR}$ ) during $75 \mathrm{~g}$-oral glucose tolerance test (OGTT) in individuals with normal glucose tolerance (NGT), impaired glucose tolerance (IGT), and type 2 diabetes (T2DM) as a function of the $2 \mathrm{~h}$ plasma glucose (PG) concentration in lean and obese subjects. $\Delta \mathrm{l} / \Delta \mathrm{G}$; insulinogenic index $\left(\Delta\right.$ nsulin $_{0-30 \mathrm{~min}} / \Delta$ Glucose - $\left.30 \mathrm{~min}\right), \mathrm{IR}$; homeostasis model assessment of insulin resistance (HOMA-IR; fasting insulin $(\mathrm{mU} / \mathrm{l}) \times$ glucose $(\mathrm{mmol} / \mathrm{l}) / 22.5)$. Adapted from ref [10].

Therefore, even though plasma insulin concentration is often higher in patients with T2DM than in normoglycemic individuals, this does not mean that patients with T2DM have greater beta cell function. In fact, true beta cell function is consistently reported to be reduced in patients with T2DM [9-11].

\section{Change in Beta Cell Function in Obesity and T2DM}

Since the development of the disposition index, beta cell function has been consistently reported to be reduced in patients with T2DM [9-11]. DeFronzo et al. reported that beta cell function calculated as insulin secretion/insulin resistance (disposition index) progressively decreases with deterioration of plasma glucose level (Figure 2) [10]. They reported that beta cell function is already decreased by $80 \%$ in patients with impaired glucose tolerance (IGT), and even more in patients with T2DM.

Interestingly, beta cell function starts to decline even within the normal range of glucose tolerance, as shown in Figure 2. More importantly, the decline of beta cell function with higher glucose level appears to be similar in lean and obese subjects, suggesting that the significance of beta cell function in the development of glucose intolerance is independent of the presence of obesity.

Longitudinal observation has also revealed a progressive decline of beta cell function in patients with T2DM over years [12,13]. The slope of the decline of beta cell function suggested that beta cell function starts to decline 10 years before the diagnosis of T2DM [12].

Studies have shown that the decline in beta cell function is related to treatment failure $[14,15]$. Less beta cell function appears to correlate with poor glycemic control, and especially greater postprandial glycemic excursion [16,17].

\section{Ethnic Difference in Insulin Secretion-Insulin Sensitivity Relationship}

$\mathrm{T} 2 \mathrm{DM}$ is a heterogenous disease. It is well recognized that patients with T2DM show various combinations of beta cell dysfunction and insulin resistance. Recently, studies have suggested that heterogeneity of T2DM also exists between ethnicities.

It has been reported that Asians are less obese than Caucasians $[18,19]$. The definition of obesity for Asians is body mass index (BMI) of $25 \mathrm{~kg} / \mathrm{m}^{2}$ or more [20,21], which is different from that for Caucasians of $30 \mathrm{~kg} / \mathrm{m}^{2}$ or more. The mean BMI of Japanese patients with T2DM is approximately $23 \mathrm{~kg} / \mathrm{m}^{2}$, while that of Caucasian patients with T2DM is approximately $32 \mathrm{~kg} / \mathrm{m}^{2}$ [18]. It is of note that the mean BMI of Japanese patients is less than $25 \mathrm{~kg} / \mathrm{m}^{2}$, the definition of obesity in Japan, implying that more than a half of Japanese patients with T2DM are not even obese.

These phenotypic differences between Asians and Caucasians suggest that there is a difference in the pathophysiology of T2DM between ethnic groups. It was suggested that plasma insulin level was lower in Japanese than in Caucasians; however, a direct comparison has not been performed. Recently, Kodama et al. reported a meta-analysis of the ethnic difference in the insulin secretion-insulin sensitivity relationship (Figure 3) [22]. In their study, in the combined subjects of three ethnic groups (Caucasian, African and Asian) with normal glucose tolerance (NGT), the individual cohort of the insulin secretioninsulin sensitivity relationship was plotted on a single hyperbolic curve, showing that the disposition index is the same among ethnicities as long as subjects are normoglycemic. However, when the subjects were divided by ethnicities, Asians were characterized by higher insulin sensitivity and lower insulin secretion compared with Caucasians and Africans.

Thus, recent evidence suggests that there is a difference in the pathophysiological features of T2DM between ethnicities, and Asians seem to have less beta cell functional capacity compared to Caucasians.

\section{Change in Beta Cell Mass in T2DM}

Beta cell function progressively declines with the progression to glucose intolerance. However, since it is not possible to measure beta cell mass in vivo in humans, the change in beta cell mass during the development of T2DM remains largely unknown.

Since the plasma insulin level is higher in patients with T2DM compared to non-diabetic subjects, it has often been believed that the beta cell mass in patients with T2DM is hyperplastic or at least normal. However, recent histological analyses have consistently shown reduced beta cell mass in patients with T2DM. In 2003, Butler et al. reported

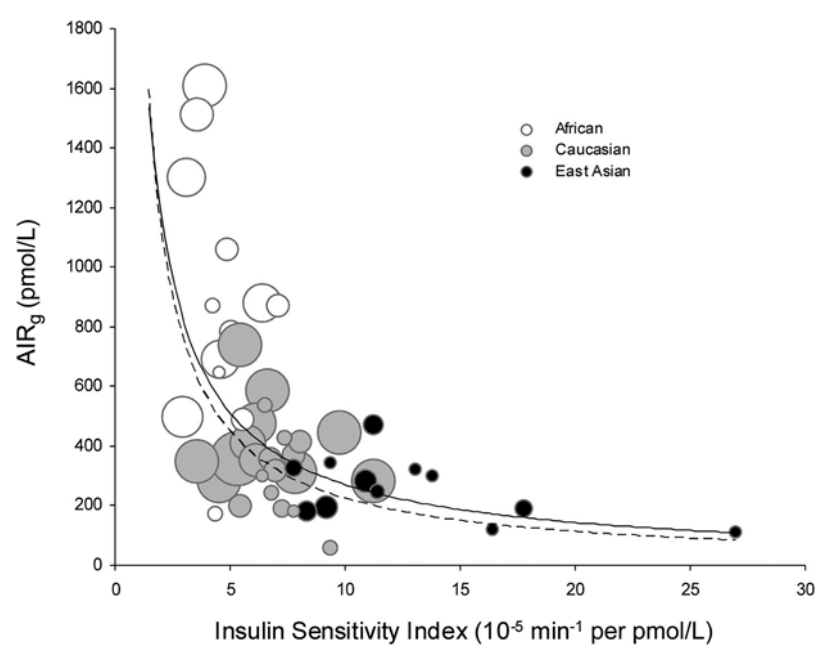

Figure 3: Ethnic differences in insulin secretion (AIR )-insulin sensitivity (SI) relationship in normal glucose tolerance (NGT) cohorts. Scatterplot of $S_{1}$ vs. AIR measured in NGT (healthy) African, Caucasian, and East Asian cohorts. Each circle represents one study cohort. Circle area is proportional to cohort sample size. AIR ; acute insulin response to glucose, $\mathrm{SI}$; insulin sensitivity index during frequently sampled intravenous glucose tolerance test. Adapted from ref [22]. 
that the beta cell mass is reduced by approximately $65 \%$ in patients with T2DM compared with age- and BMI-matched non-diabetic controls (Figure 4) [23]. Others reported a 30 to $40 \%$ decrease in beta cell mass in patients with T2DM [24-26].

If the beta cell mass is decreased in patients with T2DM, the next question is whether the beta cell dysfunction observed in T2DM is due to functional abnormality of beta cells or to a reduced number of beta cells. This issue has been repeatedly debated since 2003; however, the current consensus seems to be that there is no single mechanism for beta cell dysfunction in T2DM and it is not possible to clearly separate these two factors of beta cells. This seems true because if there is a dying cell, the function of the cell must not be normal. Thus, collectively, the expression "functional beta cell mass" has been recently used to address this issue.

To date, there are limited data on the correlation between beta cell mass and plasma glucose level. Ritzel et al. reported a hyperbolic relationship between beta cell mass and fasting plasma glucose level in humans [27]. Their results indicated that when the beta cell mass is reduced to $50 \%$ of the normal level, fasting plasma glucose starts to rise. A similar relationship between beta cell mass and plasma glucose level was also observed in rodents and monkeys [28,29]. Meier et al. reported that beta cell mass is significantly correlated with plasma C-peptide level in humans undergoing pancreatic surgery [30].

Collectively, recent histological analyses of beta cell mass clearly showed that beta cell mass is, at least to some extent, correlated with glucose intolerance in humans $[27,30]$.

\section{Mechanisms of Reduced Beta Cell Mass in T2DM}

Theoretically, the amount of beta cell mass is regulated by new beta cell formation (input) and beta cell loss (output) (Figure 5). Several sources of new beta cell formation are proposed; replication of preexisting beta cells $[31,32]$, neogenesis from duct cells or stem cells $[33,34]$ and transdifferentiation from acinar cells $[35,36]$ or alpha cells [37]. Although replication of pre-existing beta cells seems to be the main source of new beta cell formation in mice [31,32] and in humans during the postnatal period [38], the source of new beta cells in adult humans remains unclear. Histological studies suggest that beta cell replication is extremely rare in adult humans [39]. In mice, beta cell replication is more frequently observed than in humans; however, most studies used juvenile mice and it has been reported that beta cell replication markedly declines in aged mice [40].

Beta cell loss seems to mostly consist of beta cell apoptosis in vivo. Several reports confirmed a significant increase in beta cell apoptosis in patients with T2DM. Various underlying mechanisms of beta cell apoptosis in T2DM have been proposed, such as glucotoxicity [41],

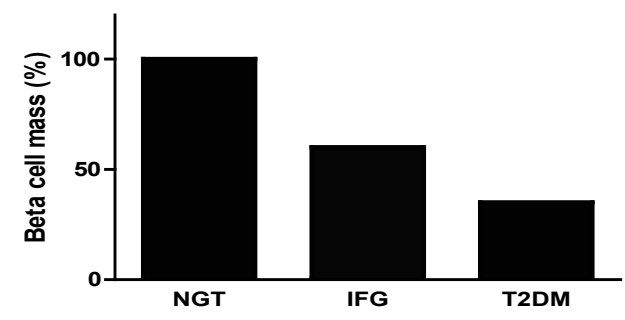

Figure 4: Beta cell mass in patients with normal glucose tolerance (NGT) impaired fasting glycemia (IFG) and type 2 diabetes (T2DM). Adapted and modified from the study by Butler et al. [23].
New beta cell formation

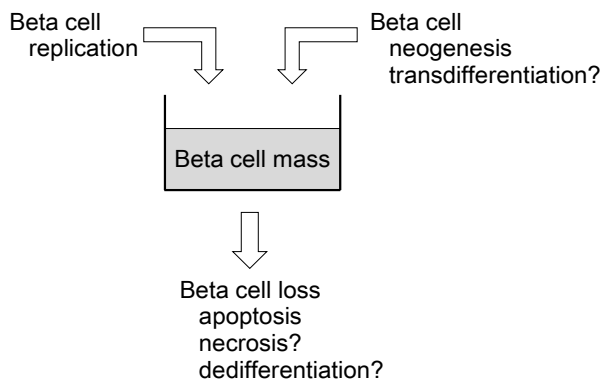

Figure 5: Regulation of beta cell mass. Beta cell mass is regulated by new beta cell formation (input) and beta cell loss (output).

lipotoxicity [42], oxidative stress [43], amyloid formation [44], altered autophagy [45] and endoplasmic reticulum (ER) stress [46]. It has been suggested that necrosis of beta cells is also increased in T2DM [47]

Recently, dedifferentiation of beta cells to alpha cells has been proposed as a novel mechanism of beta cell loss in diabetes [37]. Dedifferentiation of beta cells to alpha cells may also explain the increase in alpha cell to beta cell ratio in patients with T2DM, although whether the alpha cell mass increases in patients with T2DM remains controversial [24-26].

\section{Change in Beta Cell Mass with Obesity}

Beta cell mass is decreased in patients with T2DM. However, the change in beta cell mass during the development of T2DM is largely unknown. Since the plasma insulin level is increased approximately 2 to 3 -fold with obesity to compensate insulin resistance [48], called hyperinsulinemia, it is widely believed that the beta cell mass is increased with obesity. This is true in rodents; in juvenile rodents, high-fat diet induced obesity results in a 3 -fold increase in beta cell mass (Figure 6), with an increase in beta cell replication [40]. In adult humans, studies have shown that the beta cell mass increases by approximately 20 to $50 \%$ in obese non-diabetic individuals $[24,39]$. This increase is statistically significant, but the magnitude of the increment is much less than that in rodents (Figure 6).

Since studies of beta cell mass in humans inevitably rely on postmortem histological study, the longitudinal change in beta cell mass has not been examined to date. Although an increase in beta cell mass was observed in obese humans, an increase in beta cell replication, which was observed in rodent studies, was not observed in obese humans [39]. Therefore, there is a significant difference in beta cell mass between lean and obese humans; however, the timing as well as the source of the increased beta cells in obese humans remains unclear.

Regarding the change in beta cell mass in the transition period between normoglycemia and T2DM, Butler et al. examined the beta cell mass in humans with impaired fasting glycemia (IFG) [23]. They found an approximately $40 \%$ decrease in beta cell mass in subjects with IFG compared with nondiabetic controls, suggesting that beta cell mass starts to decline before the development of T2DM. Meier et al. also reported an approximately $20 \%$ reduction in beta cell mass in patients with IGT [49].

Rahier et al. reported a significant negative association between duration of diabetes and beta cell mass in subjects with T2DM [24], consistent with the progressive decline in beta cell function with disease duration $[12,13,50]$. Thus, beta cell mass may progressively 
decline with disease duration of T2DM; however, whether this decline in beta cell mass starts before the onset of T2DM remains controversial.

\section{Ethnic Difference in Beta Cell Mass with Obesity}

Recently, we have examined the change in beta cell mass with obesity in Japanese non-diabetic individuals [51]. As a result, unexpectedly, we were not able to find a significant increase in beta cell mass in Japanese obese individuals compared with lean subjects (Figure 6). Another Japanese study also confirmed our findings [52]. These findings are inconsistent with the findings in the Caucasian population $[24,39]$. The lower degree of obesity in Japanese may be the reason for this difference. However, since the incidence of T2DM in Japanese is similar to that in Caucasians, these findings suggest that the beta cell regenerative capacity, as well as the beta cell functional capacity, may differ between Japanese and Caucasians.

\section{Conclusion}

\section{Implications for clinical practice}

Based on the current evidence described above, a hypothesis for the changes in beta cell function and beta cell mass during the progression of T2DM is summarized in Figure 7. The Western diet and physical inactivity in modern societies increase the incidence of obesity. To compensate obesity-induced insulin resistance, insulin secretion increases approximately 2 to 3 -fold to maintain normoglycemia. However, in this "normoglycemia with insulin resistance" phase, the increase in beta cell mass, if any, is $50 \%$ or less, suggesting that each beta cell secretes more insulin. Thus, beta cell workload must

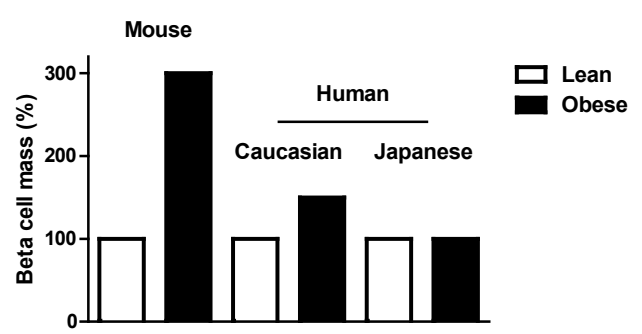

Figure 6: Change in beta cell mass with obesity. In mice, beta cell mass increases 3 -fold with obesity. In humans, a $50 \%$ increase in beta cell mass has been reported in Caucasians, while no increase was reported in Japanese. Adapted and modified from ref $[39,40,51]$

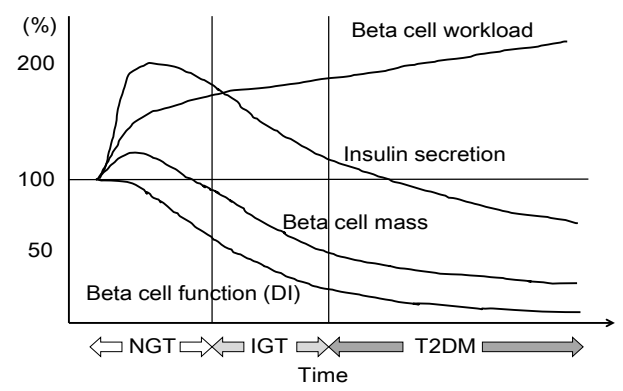

Figure 7: Hypothesis of change in beta cell function and mass during development of abnormal glucose tolerance. The magnitude of the increased demand for insulin due to insulin resistance exceeds the magnitude of beta cell mass expansion, resulting in an increase in beta cell workload. In individuals who are susceptible to type 2 diabetes (T2DM), increased beta cell workload may lead to beta cell failure and the development of T2DM. be already increased in this phase, and if the overload of beta cells persists chronically, it may cause a gradual loss of beta cell function or mass through various mechanisms such as oxidative stress, amyloid formation or ER stress. With an approximately 50\% or greater reduction in beta cell function, abnormal glucose tolerance develops. At this time, beta cell mass may also already be reduced. In addition, hyperglycemia also causes beta cell dysfunction and apoptosis, which further exacerbate beta cell failure with the eventual development of T2DM. Importantly, because insulin resistance exists continuously, the beta cell workload continues to increase, with a reduction in beta cell mass. As a result, glucose metabolism progressively deteriorates in patients with T2DM.

The current perspective suggests that beta cell failure, a loss of beta cell functional mass, occurs far before the onset of T2DM and possibly even before the onset of IGT [10]. Beta cell failure in T2DM emphasizes the importance of preservation or recovery of beta cell functional mass as a treatment strategy for T2DM [4]. Clinical trials have shown that lifestyle modification and insulin sensitizers [53-58], but not insulin secretagogues [59], are effective to prevent the development of T2DM, which is probably due to a reduction in beta cell workload. Insulin therapy has also been shown to prevent the development of T2DM [60], which is also likely to be due to a reduction in beta cell workload. Thus, reducing beta cell workload seems to be the most effective treatment strategy for T2DM to date.

A proposed concept of a treatment strategy for type 2 diabetes in relation to functional beta cell mass is shown in Figure 8. Lifestyle modification including nutritional therapy and exercise remains the most important component of treatment of T2DM at any stage of the disease. Modest weight reduction (5 10\%) by lifestyle modification has been shown to improve glycemic control and other cardiovascular risk factors, although maintained weight reduction is difficult to achieve [61,62]. Since metformin reduces insulin demand and beta cell workload through lowering hepatic glucose production, the use of metformin in addition to lifestyle modification should be considered in as early a stage of diabetes as possible, if not contraindicated. Since incretin therapy is expected to improve beta cell function in addition to its glucose-lowering effect [63], it also can be considered in a broad range of disease stage. Incretin therapy has been shown to increase beta cell mass in rodents; however, this effect has not been confirmed in humans $[64,65]$. In contrast, the use of insulin secretagogues, sulphonylureas, may not be considered as initial therapy but rather

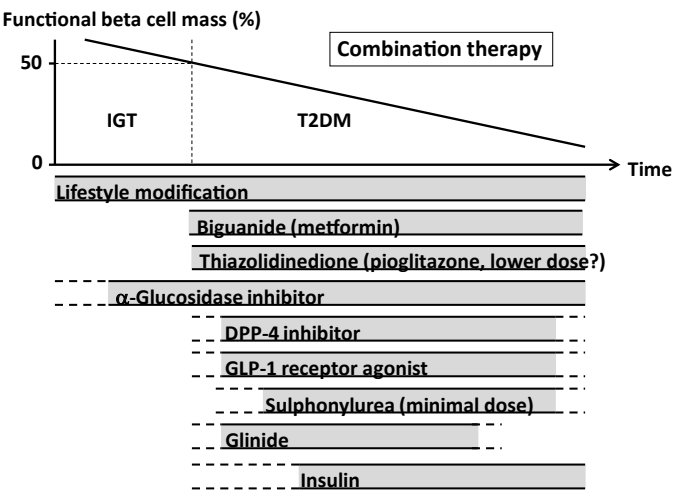

Figure 8: Proposed concept of treatment strategy for type 2 diabetes (T2DM) in relation to functional beta cell mass. An a-glucosidase inhibitor is partly approved for use in patients with impaired glucose tolerance (IGT) in Japan. Medications not approved in Japan are not included in the figure. 
used at a lower dose aiming to support the insulinotropic effect of incretin therapy. Since to date neither drug has been shown to cure diabetes, combination therapy should be considered in most cases.

Given the fact that Asians have even less beta cell functional capacity compared with Caucasians, the importance of this strategy should be further emphasized in Asian countries. New therapeutic strategies to reduce beta cell workload, including not only novel drugs but also novel socioeconomic and psychological approaches, are warranted to prevent or treat $\mathrm{T} 2 \mathrm{DM}$.

\section{Disclosure Statement}

The author declares no conflict of interest.

\section{References}

1. International Diabetes Federation (2013) IDF Diabetes Atlas, 6th edn.

2. Rhodes CJ (2005) Type 2 diabetes-a matter of beta-cell life and death? Science 307: $380-384$

3. Kahn SE (2003) The relative contributions of insulin resistance and beta-cell dysfunction to the pathophysiology of Type 2 diabetes. Diabetologia 46: 3-19.

4. DeFronzo RA, Abdul-Ghani MA (2011) Preservation of $\beta$-cell function: the key to diabetes prevention. J Clin Endocrinol Metab 96: 2354-2366.

5. Nakanishi S, Okubo M, Yoneda M, Jitsuiki K, Yamane K, et al. (2004) A comparison between Japanese-Americans living in Hawaii and Los Angeles and native Japanese: the impact of lifestyle westernization on diabetes mellitus. Biomed Pharmacother 58: 571-577

6. Funakoshi S, Fujimoto S, Hamasaki A, Fujiwara H, Fujita Y, et al. (2008) Analysis of factors influencing pancreatic beta-cell function in Japanese patients with type 2 diabetes: association with body mass index and duration of diabetic exposure. Diabetes Res Clin Pract 82: 353-358.

7. Bergman RN, Phillips LS, Cobelli C (1981) Physiologic evaluation of factors controlling glucose tolerance in man: measurement of insulin sensitivity and beta-cell glucose sensitivity from the response to intravenous glucose. $\mathrm{J}$ Clin Invest 68: 1456-1467.

8. Bergman RN, Ader M, Huecking K, Van Citters G (2002) Accurate assessment of beta-cell function: the hyperbolic correction. Diabetes 51 Suppl 1: S212-220.

9. Weyer C, Bogardus C, Mott DM, Pratley RE (1999) The natural history of insulin secretory dysfunction and insulin resistance in the pathogenesis of type 2 diabetes mellitus. J Clin Invest 104: 787-794.

10. DeFronzo RA, Eldor R, Abdul-Ghani M (2013) Pathophysiologic approach to therapy in patients with newly diagnosed type 2 diabetes. Diabetes Care 36 Suppl 2: S127-138.

11. Jensen CC, Cnop M, Hull RL, Fujimoto WY, Kahn SE; American Diabetes Association GENNID Study Group (2002) Beta-cell function is a majo contributor to oral glucose tolerance in high-risk relatives of four ethnic groups in the U.S. Diabetes 51: 2170-2178.

12. U.K. prospective diabetes study 16 (1995). Overview of 6 years' therapy of type II diabetes: a progressive disease. U.K. Prospective Diabetes Study Group. Diabetes 44: 1249-1258.

13. Kahn SE, Haffner SM, Heise MA, Herman WH, Holman RR, et al. (2006) Glycemic durability of rosiglitazone, metformin, or glyburide monotherapy. N Engl J Med 355: 2427-2443.

14. Kahn SE, Lachin JM, Zinman B, Haffner SM, Aftring RP, et al. (2011) Effects of rosiglitazone, glyburide, and metformin on $\beta$-cell function and insulin sensitivity in ADOPT. Diabetes 60: 1552-1560.

15. Matthews DR, Cull CA, Stratton IM, Holman RR, Turner RC (1998) UKPDS 26 Sulphonylurea failure in non-insulin-dependent diabetic patients over six years. UK Prospective Diabetes Study (UKPDS) Group. Diabet Med 15: 297-303.

16. Saisho Y, Kou K, Tanaka K, Abe T, Shimada A, et al. (2013) Association between beta cell function and future glycemic control in patients with type 2 diabetes. Endocr J 60: 517-523.

17. Saisho Y, Tanaka K, Abe T, Shimada A, Kawai T, et al. (2011) Glycated albumin to glycated hemoglobin ratio reflects postprandial glucose excursion and relates to beta cell function in both type 1 and type 2 diabetes. Diabetol Int 2: 146-153
18. Sone $\mathrm{H}$, Ito $\mathrm{H}$, Ohashi $\mathrm{Y}$, Akanuma $\mathrm{Y}$, Yamada $\mathrm{N}$; Japan Diabetes Complication Study Group (2003) Obesity and type 2 diabetes in Japanese patients. Lance 361: 85 .

19. Hsu WC, Boyko EJ, Fujimoto WY, Kanaya A, Karmally W, et al. (2012) Pathophysiologic differences among Asians, native Hawaiians, and other Pacific Islanders and treatment implications. Diabetes Care 35: 1189-1198.

20. Kanazawa M, Yoshiike N, Osaka T, Numba Y, Zimmet P, et al. (2002) Criteria and classification of obesity in Japan and Asia-Oceania. Asia Pac J Clin Nutr 11 Suppl 8: S732-737.

21. Examination Committee of Criteria for 'Obesity Disease' in Japan; Japan Society for the Study of Obesity (2002) New criteria for 'obesity disease' in Japan. Circ J 66: 987-992.

22. Kodama K, Tojjar D, Yamada S, Toda K, Patel CJ, et al. (2013) Ethnic differences in the relationship between insulin sensitivity and insulin response: a systematic review and meta-analysis. Diabetes Care 36: 1789-1796.

23. Butler AE, Janson J, Bonner-Weir S, Ritzel R, Rizza RA, et al. (2003) Betacell deficit and increased beta-cell apoptosis in humans with type 2 diabetes. Diabetes 52: 102-110.

24. Rahier J, Guiot Y, Goebbels RM, Sempoux C, Henquin JC (2008) Pancreatic beta-cell mass in European subjects with type 2 diabetes. Diabetes Obes Metab 10 Suppl 4: 32-42.

25. Yoon KH, Ko SH, Cho JH, Lee JM, Ahn YB, et al. (2003) Selective beta-cell loss and alpha-cell expansion in patients with type 2 diabetes mellitus in Korea. $J$ Clin Endocrinol Metab 88: 2300-2308

26. Sakuraba H, Mizukami H, Yagihashi N, Wada R, Hanyu C, et al. (2002) Reduced beta-cell mass and expression of oxidative stress-related DNA damage in the islet of Japanese Type II diabetic patients. Diabetologia 45: 85-96.

27. Ritzel RA, Butler AE, Rizza RA, Veldhuis JD, Butler PC (2006) Relationship between beta-cell mass and fasting blood glucose concentration in humans. Diabetes Care 29: 717-718.

28. Matveyenko AV, Butler PC (2006) Beta-cell deficit due to increased apoptosis in the human islet amyloid polypeptide transgenic (HIP) rat recapitulates the metabolic defects present in type 2 diabetes. Diabetes 55: 2106-2114.

29. Saisho Y, Butler AE, Manesso E, Galasso R, Zhang L, et al. (2010) Relationship between fractional pancreatic beta cell area and fasting plasma glucose concentration in monkeys. Diabetologia 53: 111-114.

30. Meier JJ, Menge BA, Breuer TG, Müller CA, Tannapfel A, et al. (2009) Functiona assessment of pancreatic beta-cell area in humans. Diabetes 58: 1595-1603.

31. Dor Y, Brown J, Martinez OI, Melton DA (2004) Adult pancreatic beta-cells are formed by self-duplication rather than stem-cell differentiation. Nature 429: 41-46.

32. Xiao X, Chen Z, Shiota C, Prasadan K, Guo P, et al. (2013) No evidence for $\beta$ cell neogenesis in murine adult pancreas. J Clin Invest 123: 2207-2217.

33. Inada A, Nienaber C, Katsuta H, Fujitani Y, Levine J, et al. (2008) Carbonic anhydrase II-positive pancreatic cells are progenitors for both endocrine and exocrine pancreas after birth. Proc Natl Acad Sci U S A 105: 19915-19919.

34. Al-Hasani K, Pfeifer A, Courtney M, Ben-Othman N, Gjernes E, et al. (2013) Adult duct-lining cells can reprogram into $\beta$-like cells able to counter repeated cycles of toxin-induced diabetes. Dev Cell 26: 86-100.

35. Zhou Q, Brown J, Kanarek A, Rajagopal J, Melton DA (2008) In vivo reprogramming of adult pancreatic exocrine cells to beta-cells. Nature 455 627-632.

36. Baeyens L1, Lemper M2, Leuckx G2, De Groef S2, Bonfanti P2, et al. (2013) Transient cytokine treatment induces acinar cell reprogramming and regenerates functional beta cell mass in diabetic mice. Nat Biotechnol .

37. Talchai C, Xuan S, Lin HV, Sussel L, Accili D (2012) Pancreatic $\beta$ cell dedifferentiation as a mechanism of diabetic $\beta$ cell failure. Cell 150: 1223-1234.

38. Meier JJ, Butler AE, Saisho Y, Monchamp T, Galasso R, et al. (2008) Beta-cel replication is the primary mechanism subserving the postnatal expansion of beta-cell mass in humans. Diabetes 57: 1584-1594.

39. Saisho Y, Butler AE, Manesso E, Elashoff D, Rizza RA, et al. (2013) b-cell mass and turnover in humans: Effects of obesity and aging. Diabetes Care 36: 111-117.

40. Tschen SI, Dhawan S, Gurlo T, Bhushan A (2009) Age-dependent decline in 
Citation: Saisho Y (2014) Obesity, Type 2 Diabetes and Beta Cell Failure: An Asian Perspective. J Mol Genet Med S1: 008. doi: 10.4172/1747-0862. S1-008

beta-cell proliferation restricts the capacity of beta-cell regeneration in mice. Diabetes 58: 1312-1320

41. Poitout V, Robertson RP (2008) Glucolipotoxicity: fuel excess and beta-cell dysfunction. Endocr Rev 29: 351-366.

42. Kusminski CM, Shetty S, Orci L, Unger RH, Scherer PE (2009) Diabetes and apoptosis: lipotoxicity. Apoptosis 14: 1484-1495.

43. Robertson RP (2010) Antioxidant drugs for treating beta-cell oxidative stress in type 2 diabetes: glucose-centric versus insulin-centric therapy. Discov Med 9: 132-137.

44. Haataja L, Gurlo T, Huang CJ, Butler PC (2008) Islet amyloid in type 2 diabetes, and the toxic oligomer hypothesis. Endocr Rev 29: 303-316.

45. Masini M, Bugliani M, Lupi R, del Guerra S, Boggi U, et al. (2009) Autophagy in human type 2 diabetes pancreatic beta cells. Diabetologia 52: 1083-1086.

46. Eizirik DL, Cardozo AK, Cnop M (2008) The role for endoplasmic reticulum stress in diabetes mellitus. Endocr Rev 29: 42-61.

47. Fujimoto K, Ford EL, Tran H, Wice BM, Crosby SD, et al. (2010) Loss of Nix in $\mathrm{Pdx} 1$-deficient mice prevents apoptotic and necrotic $\beta$ cell death and diabetes. J Clin Invest 120: 4031-4039.

48. Polonsky KS, Given BD, Van Cauter E (1988) Twenty-four-hour profiles and pulsatile patterns of insulin secretion in normal and obese subjects. J Clin Invest 81: 442-448.

49. Meier JJ, Breuer TG, Bonadonna RC, Tannapfel A, Uhl W, et al. (2012) Pancreatic diabetes manifests when beta cell area declines by approximately $65 \%$ in humans. Diabetologia 55: 1346-1354.

50. Saisho Y, Tanaka K, Abe T, Shimada A, Kawai T, et al. (2012) Effect of obesity on declining beta cell function after diagnosis of type 2 diabetes: a possible link suggested by cross-sectional analysis. Endocr J 59: 187-195.

51. Kou K, Saisho Y, Satoh S, Yamada T, Itoh H (2013) Change in $\beta$-cell mass in Japanese nondiabetic obese individuals. J Clin Endocrinol Metab 98: $3724-$ 3730 .

52. Mizukami H, Takahashi K, Inaba W, Osonoi S, Kamata K, et al. (2013) Ageassociated changes of islet endocrine cells and the effects of body mass index in Japanese. J Diabetes Invest (in press)

53. Tuomilehto J, Lindström J, Eriksson JG, Valle TT, Hämäläinen H, et al. (2001) Prevention of type 2 diabetes mellitus by changes in lifestyle among subjects with impaired glucose tolerance. N Engl J Med 344: 1343-1350.

54. Knowler WC, Barrett-Connor E, Fowler SE, Hamman RF, Lachin JM, et al.
(2002) Reduction in the incidence of type 2 diabetes with lifestyle intervention or metformin. N Engl J Med 346: 393-403.

55. Diabetes Prevention Program Research Group, Knowler WC, Fowler SE Hamman RF, Christophi CA, et al. (2009) 10-year follow-up of diabetes incidence and weight loss in the Diabetes Prevention Program Outcomes Study. Lancet 374: 1677-1686.

56. Chiasson JL, Josse RG, Gomis R, Hanefeld M, Karasik A, et al. (2002) Acarbose for prevention of type 2 diabetes mellitus: the STOP-NIDDM randomised trial. Lancet 359: 2072-2077.

57. DeFronzo RA, Tripathy D, Schwenke DC, Banerji M, Bray GA, et al. (2011) Pioglitazone for diabetes prevention in impaired glucose tolerance. $N$ Engl Med 364: 1104-1115.

58. DREAM (Diabetes REduction Assessment with ramipril and rosiglitazone Medication) Trial Investigators, Gerstein HC, Yusuf S, Bosch J, Pogue J, et al. (2006) Effect of rosiglitazone on the frequency of diabetes in patients with impaired glucose tolerance or impaired fasting glucose: a randomised controlled trial. Lancet 368: 1096-1105.

59. NAVIGATOR Study Group, Holman RR, Haffner SM, McMurray JJ, Bethe $M A$, et al. (2010) Effect of nateglinide on the incidence of diabetes and cardiovascular events. N Engl J Med 362: 1463-1476.

60. ORIGIN Trial Investigators, Gerstein HC, Bosch J, Dagenais GR, Díaz R, et al. (2012) Basal insulin and cardiovascular and other outcomes in dysglycemia. N Engl J Med 367: 319-328.

61. Wing RR, Lang W, Wadden TA, Safford M, Knowler WC, et al. (2011) Benefits of modest weight loss in improving cardiovascular risk factors in overweigh and obese individuals with type 2 diabetes. Diabetes Care 34: 1481-1486.

62. Look AHEAD Research Group, Wing RR, Bolin P, Brancati FL, Bray GA, et al. (2013) Cardiovascular effects of intensive lifestyle intervention in type 2 diabetes. N Engl J Med 369: 145-154.

63. Drucker DJ, Nauck MA (2006) The incretin system: glucagon-like peptide-1 receptor agonists and dipeptidyl peptidase-4 inhibitors in type 2 diabetes. Lancet 368: 1696-1705.

64. Bunck MC, Cornér A, Eliasson B, Heine RJ, Shaginian RM, et al. (2011) Effects of exenatide on measures of $\beta$-cell function after 3 years in metformin-treated patients with type 2 diabetes. Diabetes Care 34: 2041-2047.

65. Foley JE, Bunck MC, Möller-Goede DL, Poelma M, Nijpels G, et al. (2011) Beta cell function following 1 year vildagliptin or placebo treatment and after 12 week washout in drug-naive patients with type 2 diabetes and mild hyperglycaemia: a randomised controlled trial. Diabetologia 54: 1985-1991. 